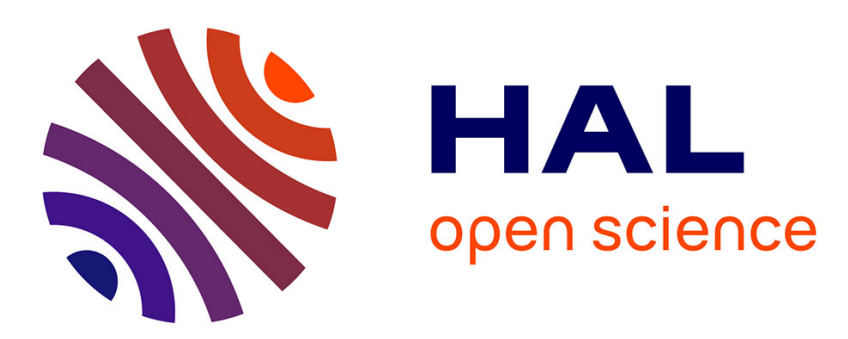

\title{
Phylogeography and Population Dynamics of the Eastern Mediterranean Whiting (Merlangius merlangus) from the Black Sea, the Turkish Straits System, and the North Aegean Sea
}

Asli Şalcioglu, Chrysoula Gubili, Grigorios Krey, Adem Yavuz Sönmez, Raşit Bilgin

\section{To cite this version:}

Asli Şalcioglu, Chrysoula Gubili, Grigorios Krey, Adem Yavuz Sönmez, Raşit Bilgin. Phylogeography and Population Dynamics of the Eastern Mediterranean Whiting (Merlangius merlangus) from the Black Sea, the Turkish Straits System, and the North Aegean Sea. Fisheries Research, 2020, 229, pp.105614. 10.1016/j.fishres.2020.105614 . hal-02882944

\section{HAL Id: hal-02882944 https://hal.science/hal-02882944}

Submitted on 28 Jun 2020

HAL is a multi-disciplinary open access archive for the deposit and dissemination of scientific research documents, whether they are published or not. The documents may come from teaching and research institutions in France or abroad, or from public or private research centers.
L'archive ouverte pluridisciplinaire HAL, est destinée au dépôt et à la diffusion de documents scientifiques de niveau recherche, publiés ou non, émanant des établissements d'enseignement et de recherche français ou étrangers, des laboratoires publics ou privés. 
Phylogeography and Population Dynamics of the Eastern Mediterranean Whiting (Merlangius merlangus) from the Black Sea, the Turkish Straits System, and the North Aegean Sea

\author{
ASLI ŞALCIOĞLU ${ }^{1 *}$, CHRYSOULA GUBILI ${ }^{2}$, GRIGORIOS KREY $^{2}$, ADEM \\ YAVUZ SÖNMEZ ${ }^{3}$, RAŞIT BÍLGIN ${ }^{1}$
}

\footnotetext{
${ }^{1}$ Institute of Environmental Sciences, Boğaziçi University, Bebek-İstanbul, Turkey.

${ }^{2}$ Hellenic Agricultural Organization-DEMETER, Fisheries Research Institute, NeaPeramos, Kavala, 64007, Greece

${ }^{3}$ Kastamonu University, Faculty of Fisheries, Merkez, Kastamonu, Turkey.
}

Corresponding author

*email: asli.salcioglu@gmail.com 


\section{ABSTRACT}

2 In this study, the taxonomic resolution and phylogenetic relationship of two presumed

3 subspecies of Merlangius merlangus, namely M. m. euxinus and M. m. merlangus, were

4 investigated. In addition, the effect of the Turkish Straits System on the evolutionary

5 history and genetic structure of $M$. merlangus, was explored. The mitochondrial

6 cytochrome $c$ oxidase subunit 1 and cytochrome $b$ genes, and the nuclear recombination

7 activating gene-1 were analysed. Our results indicate no clear distinction between the

8 two presumed subspecies, which is attributed to the low resolution of recombination

9 activating gene-1 and/or presence of potential gene flow between the two subspecies.

10 The temporal pattern of divergence between the two presumed subspecies related to the

11 Last Glacial Maximum (219 Kya), whereas the expansion of each main sampling 12 location occurred after the flooding of the Black Sea by salt water from the

13 Mediterranean (5 Kya), following a period of stability. Additionally, significant genetic

14 differences are observed among the North Aegean samples and the collections from the

15 Turkish Straits System and the Black Sea, along with some significant structure among sampling sites located in the Turkish Straits System and Black Sea. The lower genetic variability of the eastern Mediterranean M. merlangus when compared to Atlantic ones might be due to a potential population bottleneck before the last glacial period, a trend that is commonly found in these waters.

Key words: Turkish Straits System, mitochondrial DNA, population structure, divergence, Gadoid. 


\section{INTRODUCTION}

Molecular phylogeographic studies have been used to resolve taxonomic relationships among species and assess evolutionary processes that can explain population diversity in time and space (Avise, 2000). In the marine environment where boundaries are not easily determined, molecular tools have proven to be extremely important in delineating species structure in fragmented geographical areas, and understanding dispersal patterns of organisms (Patarnello et al., 2007). Furthermore, analyses with these molecular tools can contribute to the conservation of individual species, and identification of marine protected areas (Avise et al., 1987). Previous studies of marine fishes have shown that biogeographical barriers and differences in environmental and oceanographic factors could affect population connectivity and cause strong genetic differences among stocks (Durand et al, 2013; Magoulas et al., 1996). Such knowledge is extremely important for the effective management of commercially important fish species, particularly in areas with pronounced geographical and oceanographic gradients, such as the Eastern Mediterranean.

The Turkish Straits System (TSS), consisting of the Bosphorus, the Sea of Marmara and the Dardanelles, plays a significant biogeographical role as the major connection between the Black Sea and the Mediterranean (Öztürk, 1998). The system serves as a barrier and/or a corridor for various marine species due to its distinguishing hydrographical characteristics (Öztürk and Öztürk, 1996). It acts as a physical barrier against dispersal of fish (Magoulas et al., 1996, 2006; Turan et al., 2009a, 2009b;

47 Durand et al., 2013), fish larvae (Moraitou-Apostolopoulou, 1985), zooplanktonic 
TSS also acts as a biological corridor for migratory species of fish (Turan et al., 2006) from the Black

Sea and the Mediterranean Sea, and as feeding and spawning grounds for pelagic fish of Atlantic origin (Acara, 1957; Akşiray, 1987; Kocataş et al., 1993) during their migration from the Black Sea to the Sea of Marmara, or vice versa. Some examples include the bluefish (Pomatomus saltatrix) (Turan et al., 2006), the Mediterranean turbot (Scophthalmus maximus) (Suziki et al., 2004) and the flounder (Platichthys flesus luscus) (Borsa et al., 1997).

Merlangius merlangus (Linnaeus, 1758) (Gadidae) is a marine benthopelagic fish, found predominantly in the Northern hemisphere and in circumpolar temperate waters. It is presumed to be divided into two subspecies based on geographical distribution, and diagnostic morphological characters. The North Atlantic Ocean whiting, Merlangius merlangus merlangus (Linnaeus, 1758), that occurs along the European coasts from Iceland and south-western Barents Sea, to the western Baltic and the northern coasts of Portugal, exhibits a restricted distribution in the western Mediterranean. Conversely, Merlangius merlangus euxinus (Nordmann, 1840) inhabits the Black Sea, the adjoining areas of the Azov Sea, the Sea of Marmara, the Aegean, and the Adriatic Sea (Bailly, 2008; Parin et al., 2014). The two presumed subspecies are identified by the following diagnostic features: $M$. m. euxinus has a small barbel, and a pectoral fin reaching about $15.4-18.2 \%$ of the body length, while $M . m$. merlangus does not have a barbel and its pectoral fin is around 13.8-15.6\% of the body length (Whitehead et al., 1986).

Both presumed subspecies are of high commercial importance in their respective distributional ranges. In the Baltic Sea, M. merlangus is considered as Vulnerable due to a $30 \%$ decline of stocks over the last 12 years (HELCOM, 2013). In the Mediterranean 
and Black Sea, however, M. merlangus has been reported as Least Concern (IUCN, 2011). According to FAO Working Group on the Black Sea report (FAO, 2017), whiting has been overexploited in recent years (1994-2015). The total mean annual catch of whiting among Black Sea countries [(Bulgaria, Georgia, Romania, Russian and Ukraine (excluding Turkey)] was less than 0.6 thousand tons between 1996-2005 (Shlyakhov and Charova, 2003). Turkey is the only country in the Black Sea with targeted trawling fisheries for whiting with mean annual catches dropping by approximately 40\% between 1986-1995 and 1996-2005 (from 17.6 thousand tons to 10.8 thousand tons, respectively), showing a general trend of decline in stocks. Ilegal and unregulated fishing are the main threats that affect their abundance in the Black Sea (Özdemir et al., 2018).

Studies on the population structure of the whiting (Merlangius merlangus) revealed contrasting results. Nuclear markers, such as microsatellites, showed a small scale spatial structure in the North Atlantic (Rico et al., 1997; Charrier et al., 2007), whereas high gene flow was detected using the cytochrome $c$ oxidase subunit I (COI) mitochondrial gene among sites in the North East Atlantic (Eiriksson and Arnason, 2014). Additionally, Bektas and Belduz (2007) detected two main groups among M. m. euxinus populations in the Black Sea using Random Amplified Polymorphic DNA (RAPD) markers, whereas morphometric and meristic characters verified the presence of one stock in the area (İşmen, 1995, 2001). However, no taxonomic resolution of the two presumed subspecies of Merlangius merlangus has been previously investigated along the species' distribution. Here, we undertook multilocus analyses using both mitochondrial DNA (mtDNA) (COI and cytochrome $b$, cyt-b) and nuclear DNA (nuDNA) (Recombination Activating Gene-1, RAG1) markers. Intra- and interpopulation analyses were applied to examine the taxonomic limits of the presumed 
Merlangius subspecies. Additionally, phylogeographic analyses are presented to address intraspecific genetic structure, assess the stock status in the Northeastern Mediterranean Sea, and estimate the demographic history of $M$. m. euxinus populations.

\section{MATERIALS AND METHODS}

\subsection{Sampling sites}

Individuals of Merlangius merlangus euxinus were collected from eight stations, four in the Black Sea (Rize, Sinop, Inebolu and Zonguldak in Turkey), three in the TSS (Istanbul, Bandirma and Canakkale in Turkey), and one in the North Aegean Sea (Thermaikos Gulf in Greece). These areas (Black Sea, TSS and the North Aegean Sea) are described herein as the main sampling locations. Additionally, two Merlangius merlangus merlangus specimens were collected from one sampling station along the north coast of France (Ault) (Fig. 1, Supplementary Table 1). A total of 233 specimens were collected from otter trawl and handline fisheries between 2013-2015. Additionally, GenBank entries were included in the data set (Fig. 1, Supplementary Tables 1 and 2). The detailed descriptions (locations, references and regions) of all samples are provided in Fig. 1, and the Supplementary Tables 1, 2 and 3. Tissue was preserved in $80 \%$ ethanol at room temperature in the field, and at $-20{ }^{\circ} \mathrm{C}$ in the laboratory, until further processing.

\subsection{DNA extraction, amplification and sequencing of genetic markers}

Genomic DNA was isolated from the muscle or caudal fin tissue with a PureLink ${ }^{\circledR}$ Genomic DNA Kit (Invitrogen, Carlsbad, USA), following the manufacturer's protocols. The mtDNA and nuDNA fragments were amplified via Polymerase Chain 
124 Reaction (PCR) using the primers COI-Fish-F1 and COI-Fish-R1 (Eiriksson and 125 Arnason, 2014; Kochzius et al., 2010) for COI, GluDg and Cb3h (Roques et al., 2006) 126 for cyt-b, and newly designed primers for RAG1 (Supplementary Table 4).

127 Amplifications were perfomed in a total volume of $25 \mu \mathrm{L}$ using different PCR profiles 128 and amplification conditions per gene (Supplementary Appendix SI). All amplified 129 products were purified and sequenced commercially (Macrogen Europe, Amsterdam, 130 The Netherlands).

\subsection{Phylogenetic analyses}

133 All chromotograms were edited and aligned manually with Sequencher v.5.4.1 134 (GeneCodes Corp.). The mtDNA PCR products were sequenced in the forward direction, as there were no indications of heterozygous sites. The resulting alignments were verified by eye. Additionally, stop codons were investigated for mtDNA genes to determine presence/absence of mitochondrial pseudogenes by using DAMBE v.6.4.1 (Xia, 2017). Finally, potential amplification/sequencing errors were controlled by aligning all sequences to detect polymorphic sites and subsequently confirming the clarity of the peaks at these sites. The nuDNA products were sequenced bidirectionally to verify the presence/absence of heterozygous sites that were also confirmed in Sequencher.

The models of sequence evolution for the protein-coding mtDNA markers with partitions and the nuclear gene were selected using the Bayesian Information Criterion in PartitionFinder v.1.1.0 (Lanfear et al., 2012) (Supplementary Table 5). Phylogenetic analysis was performed in MrBayes v.3.2.2 (Ronquist et al., 2012) with two 147 independent runs of $5 \times 10^{6}$ generations and four parallel Markov chain Monte Carlo (MCMC) chains, discarding the initial $25 \%$ as burn-in. Maximum likelihood analyses 
(ML) were performed in RAxML v.8.0 (Stamatakis et al., 2014) using 1,000 bootstrap replications. Melanogrammus aeglefinus [(DQ020497 (extracted from complete mitogenome) for COI, NC007396 for cyt-b, and AJ566336.2 for RAG1)], Gadus morhua (EU877731 for COI, NC002081 for cyt-b, and FJ215242, KP644390 for RAG1), and Merluccius merluccius (KX782819, KX782949 for COI, EU264016, EU492347 for cyt-b and JN230904 for RAG1) were used as outgroups.

\subsection{Population structure and demographic history analyses}

Number of haplotypes, haplotype diversity (h) (Nei and Tajima, 1981), nucleotide diversity $(\pi)$ (Nei, 1987), number of polymorphic sites, singleton and parsimony informative sites and the number of net nucleotide substitutions (percentage of pairwise sequence divergence) between subspecies were calculated in DnaSP v.5.10.1 (Librado and Rozas, 2009). Pairwise genetic distances between subspecies were also determined in MEGA v.7.0 (Kumar et al., 2016), based on the Kimura's two parameter model (Kimura, 1980).

Genetic differences among localities were estimated in Arlequin v.3.5.2.2 (Excoffier and Lischer, 2010) using the genetic distance-based $\Phi_{\mathrm{ST}}$ and the pairwise $F_{\mathrm{ST}}$ values using 10,000 randomizations. Bonferroni corrections (Rice, 1989) were used to adjust for the significance of the $P$ values for multiple tests. A hierarchical analysis of molecular variance (AMOVA) to test for significance of differentiation between groups (Rize, Sinop, Zonguldak, Inebolu) and iii) North Aegean Sea (Thermaikos Gulf, Greece). Analysis was performed only for M. m. euxinus due to sample size constraints. 
174 from demographic or spatial population expansion, were estimated with DnaSP. 175 Additionally, Tajima's $D$ (Tajima, 1989) and Fu's $F$ s (Fu, 1997) neutrality tests used to 176 detect population growth, as well as the raggedness statistic " $r$ " (Harpending et al., 177 1993; Harpending, 1994), which quantifies the smoothness of the fit of the observed 178 mismatch distribution to one expected under a population expansion model, were 179 performed in DnaSP. Significance of neutrality tests and $r g$ values were tested with 1,000 coalescence simulations. Past population demography of three different regions (TSS, Black Sea and North Aegean Sea) of M. m. euxinus was reconstructed using Extended Bayesian Skyline Plots (EBSP) (Heled and Drummond, 2008; Ho and Shapiro, 2011), as implemented in BEAST v.2.4.8 (Bouchkaert et al., 2014). A strict molecular clock was set using the multi-locus dataset (three genes: COI, cyt-b, RAG1), the previously selected substitution models (Supplementary Table 5), and time was scaled using the estimated rate for each marker (see Results section 3.5 Divergence time estimates). The Bayesian Markov Chain Monte Carlo (MCMC) was set for $1 \times 10^{8}$ generations, discarding the initial $10 \%$ of samples as burn-in. Convergence of runs was evaluated on TRACER v.1.6. (Rambaut et al., 2014). Visualization of the EBSP plots was done within RStudio v.1.1.463 in R v.3.5.1. (R Core Team, 2018). Finally, haplotype networks for each gene were constructed using the median joining method (Bandelt et al., 1999) as implemented in PopART v.1.7 (Leigh and Bryant, 2015).

\subsection{Divergence time estimation}

195 The evolutionary divergence time of phylogenetic separation of the two potential $M$. merlangus subspecies was estimated in BEAST. Melanogrammus aeglefinus and Gadus morhua were used as outgroups. No calibration was used, and the best substitution model for each gene was applied (Supplementary Table 5). The coalescent constant 
population size tree prior was applied to tackle divergence among closely related lineages (Ho et al., 2005), and an uncorrelated lognormal relaxed clock was used, as multiple loci can be incorporated into the analysis and also deal with different rates among loci. In order to account for the variation of substitution rates among the three genes (Chiriki-Adeeb and Chiriki, 2016), the rate for all markers was estimated. The analysis was executed twice for $2 \times 10^{8}$ generations, sampling every 5,000 generations and discarding the initial $20 \%$ as burn-in. Convergence was confirmed in TRACER v.1.6, and the effective sample sizes (ESS) for all model parameters were assessed (values higher than 200) indicating adequate sampling intensity for all parameters.

\section{RESULTS}

\subsection{Summary statistics}

212

Sequences of M. merlangus were obtained for COI (481 bp), cyt-b (611 bp) and RAG1 (346 bp) regions, for 164, 129 and 173 individuals, respectively (Supplementary Table

6). No stop codons or ambigious sites were observed in any of the COI and the cyt-b sequences. Merlangius merlangus euxinus exhibited eight haplotypes and seven polymorphic sites in the COI marker, with haplotype and nucleotide diversities of 0.1450 and 0.0003 , respectively (Supplementary Table 6). Conversely, diversity indices were higher for the cyt-b (22 haplotypes; 19 polymorphic sites, $\mathrm{h}=0.8730, \pi=0.0029$ ) and the nuclear marker (22 haplotypes; 14 polymorphic sites; $h=0.4940, \pi=0.0025$ ) (Supplementary Table 6). Interestingly, higher genetic diversity was observed along the Turkish coastline TSS (Istanbul) and Black Sea when compared to the North Aegean Sea (Thermaikos Gulf) for the mtDNA markers [COI (Black Sea: $\mathrm{h}=0.2070, \pi=$ 0.0005; TSS: Istanbul: $\mathrm{h}=0.1950, \pi=0.0004$, Thermaikos Gulf: $\mathrm{h}=0.1080, \pi=$ 
0.0002); cyt-b (Black Sea: $h=0.7970, \pi=0.0023$; TSS: $h=0.8800, \pi=0.0034$,

Thermaikos Gulf: $h=0.7460, \pi=0.0020)$ ], a trend that was generally reversed for the nuclear marker (Black Sea: $h=0.4300, \pi=0.0022$; TSS: $h=0.5050, \pi=0.0028$; Thermaikos Gulf: $\mathrm{h}=0.5660, \pi=0.0019$ ) (Supplementary Table 6). The Merlangius merlangus merlangus samples exhibited higher values in diversity indices compared to the M. m. euxinus (Supplementary Table 6), however, the results were not taken into account due to their small size $(\mathrm{n} \leq 5)$.

A total of 11 polymorphic sites were reported for the COI gene $(2.2 \%$ of $481 \mathrm{bp}$, 164 sequences), of which seven positions (1.4\%) were parsimony informative, and one genomic position (position 316) being fixed between the two potential subspecies (Supplementary Table 7). For this marker, the net pairwise sequence divergence between the presumed $M$. m. euxinus and $M$. m. merlangus groups was $0.331 \%$. Additionally, 20 polymorphic sites (3.2\% of $611 \mathrm{bp}, 129$ sequences) were detected in the cyt-b gene, of which nine positions (1.6\%) were parsimony informative. One genomic position (position 611) was diagnostic between the two subspecies (Supplementary Table 8). For cyt-b, the net pairwise sequence divergence between the M. m. euxinus and M. m. merlangus groups was $0.337 \%$. Thus, the genetic distance values for both markers between the two subspecies are very similar (approx. 0.3\%).

\subsection{Phylogenetic relationships}

Both Bayesian and ML topologies of the concatenated dataset resolved one major clade for M. merlangus. Within Merlangius, there is a shallow lineage of M. m. merlangus with a low posterior probability and bootstrap support ( 0.53 and 55, respectively) that contained samples from the Black Sea, the TSS, North Aegean and France (Supplementary Figure 1). Additionally, two shallow geographical groups were also 
revealed, one formed by the majority of the North Aegean Sea (Greece) specimens with posterior probability and bootstrap support of 0.60 and 35 , respectively, and the second comprised of fish caught along the Turkish coast (Black Sea and TSS) with high posterior probability $(>0.70)$ but low bootstrap values $(<70)$. Similar trends were detected in the topologies of the individual markers, with the inclusion of additional samples from each sampling locality (Supplementary Figs. 2-4).

\subsection{Population structure}

Pairwise $\Phi_{\mathrm{ST}}$ values for the concatenated mtDNA dataset of $M$. m. euxinus subspecies, ranged from -0.045 to 0.364 (Table 1). Most pairwise comparisons involving the North Aegean Sea and the Turkish sampling localities (Istanbul, Canakkale, Bandırma, Rize, Sinop) showed significant differentiation following Bonferroni corrections (Table 1). The highest $\Phi_{\mathrm{ST}}$ value, which remained significant after Bonferroni corrections, was observed between Canakkale and Sinop $\left(\Phi_{\mathrm{ST}}=0.364\right)$. No significant differences were observed among localities within the main two Turkish sampling areas (TSS: Istanbul, Canakkale, Bandırma; Black Sea: Rize, Sinop, Zonguldak, Inebolu). Conversely, pairwise $\Phi_{\text {ST }}$ values among three main regions (TSS, Black Sea, North Aegean Sea) were significant. Significant $\Phi_{\mathrm{ST}}$ values were observed between TSS and the Black Sea $\left(\Phi_{\mathrm{ST}}=0.141\right)$ and between TSS and the Aegean Sea $\left(\Phi_{\mathrm{ST}}=0.171\right)$ and between the Black Sea and the North Aegean Sea $\left(\Phi_{\mathrm{ST}}=0.188\right)$ (Supplementary Table 9). Hierarchical AMOVA (Table 2) showed significant variation among the three main groups $\left(\Phi_{\mathrm{CT}}=0.1580,15.80 \%\right)$. The highest percentage of genetic variation was detected within populations of these regions $\left(\Phi_{\mathrm{ST}}=0.1833,81.67 \%\right)$, however, no significant differences were detected among populations within groups $\left(\Phi_{\mathrm{SC}}=0.0300\right.$, $2.53 \%$ ) (Table 2). 

from -0.021 to 0.258 (Table 1). All but one (North Aegean Sea vs. Bandirma) pairwise comparisons between the North Aegean Sea and the Turkish sampling sites were significantly different. Moreover, no significant differences were observed among localities within the TSS (Istanbul, Çanakkale, Bandırma), a pattern that was not followed within the Black Sea sites (Rize, Sinop, Zonguldak, Inebolu), where the pair Rize and Inebolu exhibited the highest value $\left(F_{\mathrm{ST}}=0.258\right)$. Additionally, significant $F_{S T}$ values were also observed between TSS and North Aegean Sea $\left(F_{S T}=0.104\right)$ and between Black Sea and North Aegean Sea $\left(F_{S T}=0.155\right)$ (Supplementary Table 9$)$. The AMOVA analysis detected no significant variation among groups $\left(F_{\mathrm{CT}}=0.0419\right.$, $4.18 \%$ ), whereas the variation among populations within groups and within populations was significant $\left(F_{\mathrm{SC}}=0.0300\right.$ and $2.51 \% ; F_{S T}=0.0866$ and $91.34 \%$, respectively $)$ (Table 2).

\subsection{Population history of Merlangius merlangus}

A recent demographic population expansion was supported by the unimodal mismatch distributions (Supplementary Figs. 5, 6, and 7) of the three different genes from all $M$. m. euxinus main sampling localities. The population expansion model was also supported by the overall negative and significant $F_{\mathrm{S}}$ and $D$ values, as well as the nonsignificant $r g$ values (Supplementary Table 6).

No shared haplotypes were found among the presumed M. m. euxinus and M. m. merlangus individuals, whilst main haplotypes were separated by one mutational step in both mtDNA markers (Figs. 2a-b). A star-shaped haplotype network of the COI gene for the presumed $M . m$. euxinus subspecies showed that the most common haplotype (with a frequency of 79\%) was found in eight different locations in the Black Sea, TSS 
and the North Aegean Sea (Fig. 2a). A star-shaped haplotype pattern was not detected in the presumed M. m. merlangus (Fig. 2a). Interestingly, the haplotypes of the Black Sea specimens, which clustered with $M . m$. merlangus were separated by more mutational steps from the Black Sea $M . m$. euxinus than those from the Atlantic Ocean. A starshaped network comprising haplotypes from the TSS, the Black Sea and the North Aegean Sea, was also observed in M. m. euxinus for cyt-b (Fig. 2b). Additionally, three haplotypes were the most common for $M$. m. euxinus, and were found in all sampling locations (Fig. 2b). For the RAG1 gene, the haplotype network revealed that the most common haplotype (70\% of the individuals) was shared among all locations (Fig. 2c). As opposed to the mtDNA haplotype networks, the nuclear marker did not reveal any structure (Fig. 2c).

The EBSP analyses of the concatenated dataset indicated that the M. m. euxinus population size in the North Aegean Sea remained relatively constant until about 8 Kya, followed by a sharp population growth (Fig. 3a). Despite the initial trend of constant population size in the TSS and the Black Sea populations, a more recent and sharper onset of expansion (5-6 Kya) than the North Aegean was estimated (Figs. 3b-c).

\subsection{Divergence time estimates}

The divergence-time chronogram places the split between Merlangius merlangus and the two Gadoid species at an age of $\sim 3.436 \mathrm{Ma}$ (CI: $0.304-10.913 \mathrm{Ma}$ ). Within the Merlangius merlangus clade, the estimated divergence between the two presumed subspecies was about 219 Kya (CI: 25-687 Kya) (Fig. 4). The estimated mutation rates for the COI, cyt-b, and RAG1 were $5.083 \%, 3.444 \%$, and $6.510 \%$ per million years, respectively. 


\section{DISCUSSION}

\subsection{Phylogenetic analyses and genetic distances}

In this study, the phylogeography of Merlangius merlangus (sensu lato) was investigated with data from the Turkish coastal waters, the North Aegean Sea and the Atlantic region. Despite the large volume of studies describing the phylogeographical effect of the Strait of Gibraltar (Pillars of Hercules) on commercially important marine species (Rosel and Block, 1996; Ladoukakis et al., 2002; Bargelloni et al., 2003; Zardoya et al., 2004; Cimmaruta et al., 2005; Magoulas et al., 2006), little is known about the role of TSS and the underlying factors that could drive gene flow and diversification in the TSS and the seas adjacent to it.

Furthermore, there is a taxonomic uncertainty regarding the species under investigation, as two potential subspecies are often recognised in the literature: Merlangius merlangus merlangus and Merlangius merlangus euxinus (Özdamar et al., 1996; Bektas and Belduz, 2007; Nedreaas et al., 2014). The Black Sea whiting has been considered as a distinct subspecies (M. m. euxinus Nordmann, 1840), which is distinguished from $M . m$. merlangus by the presence of a barbel. However, the presence of individuals across the $M . m$. merlangus geographic distribution indicates that this character alone is not informative regarding the specific status of these presumed subspecies.

The available data from this study do not provide adequate arguments to verify or deny the subdivision of the Merlangius merlangus. For example, divergence time analyses using all three genes indicated two different subspecies lineages (Fig. 4). In addition, two geographically separated groups of $M$. m. euxinus from the North Aegean, and the TSS and the Black Sea, imply limited levels of gene flow between these water bodies. Furthermore, two geographically separated groups were also observed based on 
the genetic structure analyses. On the other hand, topologies obtained from two approaches (Supplementary Figs. 1-4) revealed shallowly differentiated lineages of $M$. m. euxinus and $M . m$. merlangus. In addition, genetic distances and number of fixed polymorphisms were small: A total of seven and nine parsimony informative sites were observed for the COI and cyt-b genes, respectively, for both presumed subspecies, whilst only one absolute genomic position was fixed for differentiating between two subspecies based on each of the two mtDNA genes. Additionally, the genetic distance between the two presumed subspecies for the COI gene was about $0.3 \%$, a value that is commonly found among conspecifics (Zhang and Hanner, 2011; Karahan et al., 2017). Furthermore, the relatively low nucleotide substitution values for both mitochondrial genes used in this study $(\mathrm{Da}=0.00331$ and $\mathrm{Da}=0.00337$ for $\mathrm{COI}$ and cyt-b genes, respectively) are consistent with the findings of distribution of genetic diversity within subspecies of other marine fish, e.g., Mullus spp. (Keskin and Can, 2009), and within other fish species, e.g. Trachurus spp. (Bektas and Belduz, 2008), and Alosa spp. (Turan et al., 2015a) from the same sampling locations, rather than between subspecies and species. Hence the signal from our data is not clear, in supporting or rejecting the (e.g. ddRAD) on the two subspecies is needed to test whether they represent different lineages or not.

The shallowly differentiated lineages of the two subspecies on the phylogenetic trees might have been influenced by different factors. Biologically speaking, gene flow between the two subspecies might be one of the reasons behind this lack of differentiation. Genetic homogeneity of the Merlangius merlangus populations, due to transportation and mixing of long-lived larvae and eggs by current system, was confirmed by the analyses of microsatellites in North Atlantic region (Rico et al., 1997; 
374 Charrier et al., 2007) and the COI gene in the Northeast Atlantic (Eiriksson and

375 Arnason, 2014). In addition, low numbers of specimens of M. m. merlangus that were sampled in our study $(\mathrm{N}=5)$ might also have contributed to the observed lack of differentiation. Finally, the RAG1 tree and haplotype network do not show indicate clear differentiation between the two presumed subspecies (e.g. there are no fixed differences between the two presumed subspecies), contributing to the lack of adequate differentiation.

\subsection{Molecular diversity, population expansion and evolutionary history}

This study revealed that the overall COI haplotype and nucleotide diversities (Supplementary Table 6) of the presumed M. m. euxinus populations were lower than those reported for the Atlantic M. m. merlangus (Eiriksson and Arnason, 2014), particularly as sample sizes were similar $\left(\mathrm{N}_{\text {Atlantic }}=139\right.$, vs. $\left.\mathrm{N}_{\text {ThisStudy }}=159\right)$. Low diversity levels in the area compared to those of the Atlantic were also observed in other fish species, such as the European sprat (Sprattus sprattus) and the thornback ray (Raja clavata) in the Mediterrenaen and the Black Sea (Chevolot et al., 2006; Debes et al., 2008; Limborg et al., 2012). Additionally, the low genetic variability of the eastern Mediterranean turbot (Scophthalmus maximus) compared to the western stock, was attributed to a population bottleneck (Suziki et al., 2004). Recent founder events, pollution and illegal fishing are also considered to be factors that negatively affect genetic diversities in marine species populations, such as Black Sea harbour porpoise (Viaud-Martínez et al., 2008). Similarly, the lower genetic variability of the eastern 
before the last glacial period and/or differences in population expansion patterns among the Atlantic and the Eastern Mediterranean/Black Sea stocks. Past glaciation cycles and associated sea level changes seem to have affected the diversification and distribution of fish species in the Mediterranean (O'Regan et al., 2011). Here, divergence among the two presumed subspecies appears to predate the last glacial period, with estimated divergence time of 219 Kya. The mid-Saalian glaciation was characterised by interglacial episodes with subsequent fluctuation in sea level that could have potentially led to the diversification of the Eastern Mediterranean whiting (Waelbroeck et al., 2002). Moreover, the last glacial maximum (LGM) seems to have promoted lineage diversification and shaped geographical distribution within $M$. merlangius euxinus in the Eastern Mediterranean (Fig. 4). The Eastern Mediterranean basin has been previously considered to be a refuge during glaciations (Ekman, 1967; Patarnello et al., 2007). The post LGM sea level rise in rates of about $15 \mathrm{~mm} /$ year from 16,000 to 12,500 and from 11,500 to 9,000 years ago (Lambeck et al., 2002) could have facilitated the dispersal and subsequent diversification of the species to the Aegean Sea. The proposed split (of approximately 219 Kya) might be consistent with a glacial or interglacial event, however, such lengthy periods of isolation should have had a stronger genetic impact on the evolution of the presumed subspecies.

The Eastern Mediterranean whiting has undergone a recent and sharp expansion in all three main sampling areas. The star-like haplotype networks, the significant negative $F$ s and $D$ values, the unimodal mismatch distributions for all markers and the three EBSP plots corroborate such suggestion. Moreover, the EBSP results of the fully concatenated dataset revealed that the North Aegean Sea population was nearly constant until $\sim 8$ Kya. It also showed that the species underwent a recent expansion, which took place after the LGM and coincided with the opening of the Dardanelles ( $~ 8$ Kya, Fig 

significantly postdate the Last Glacial Maximum ( 18 Kya) and the opening of the Dardanelles ( 8 Kya) (Fig 3b-c). The time difference ( 2000 years) between the expansion of the Black Sea and TSS (5-6 Kya) and the opening of the Dardanelles) ( 8 Kya) might be attributed to the time required to create suitable habitat conditions for the settlement and expansion of the species, as suggested in previous studies (Rohnling et al., 2009; Fontaine et al., 2012). Before the opening of the Dardanelles, the Black Sea was considered to be a freshwater lake (Zaitsev and Mamaev, 1997), therefore low salinity waters would not have been a favourable environment for the survival of a marine species. The last opening of the Dardanelles and the flooding of the Black Sea basin by salt water from the Mediterranean Sea, might have allowed the subsequent geographic dispersal and establishment of $M$. m. euxinus into the Black Sea which occurred over the last 8 Kya (Ryan et al., 1997). Therefore, the Eastern Mediterranean whiting might have dispersed and expanded firstly into the North Aegean Sea, and subsequently into the TSS and Black Sea as observed in other fish species (Durand et al., 2013). Interestingly, the Eastern Mediterranean stocks showed a more recent expansion than the North East Atlantic whiting populations. The later have undergone an earlier sudden expansion, which took place approximately 70 Kya ago (Eiriksson and Arnason, 2014), in an area where high levels of gene flow were detected. This trend could also be attributed to water temperature and water level fluctuations, as well as interactions with other species (Eiriksson and Arnason, 2014).

\subsection{Population differentiation}

446 Our results revealed a pattern of sub-structure and connectivity, with three 447 geographically defined populations (Black Sea, TSS, North Aegean Sea), and relatively 
low levels of gene flow among the sampling sites in the Black Sea and TSS. Significant genetic differentiation was observed among the main sampling locations of $M . m$. euxinus based on the concatenated mtDNA data, which was corroborated by the nuDNA marker results. Moreover, the high values of all molecular diversity indices, and the significant genetic structure between North Aegean and locations along the Turkish coast suggest that the TSS is likely to be a barrier to gene flow for $M$. m. euxinus. Despite the genetic isolation of the Black Sea and TSS from the North Aegean M. m. euxinus, low connectivity levels among Turkish sampling sites were identified in our results; a single lineage of $M$. m. euxinus was recovered (Supplementary Fig. 1) and non-significant pairwise genetic differences were also detected (Table 1). The Dardanelles Strait is extremely important to the water exchange of the Mediterranean and Black Seas systems (Kanarska and Maderich, 2008), creating differences in temperature, salinity and density between them (Sayin et al., 2011). Such physical barriers could instigate genetic substructuring despite the long pelagic stage of the species (Zheng et al., 2001). Previous studies have also highlighted that straits can act as barriers to dispersal for whiting. The Dogger Bank in the North Sea has been suggested to serve as a barrier that prevents mixing between southern and northern populations of whiting (Pilcher et al., 1989), a conclusion that has been corfirmed by genetic studies (Rico et al., 1997; Charrier et al., 2007). Similarly, differences have been reported between the Eastern Mediterranean and Black Sea Sarda sarda populations (Roberti et Interestingly, a few specimens from the Black Sea and the TSS clustered with $M$. m. merlangus samples from the Atlantic (Figs 2a-b, Supplementary Figs 2-3). As the total period of larval stages of Merlangius merlangus is longer than one month (Hislop, 
473 1984; Fischer et al., 1987), the transoceanic and/or interoceanic dispersal from the

474 Atlantic or the Mediterranean to the Black Sea is possible through ballast water 475 discharge. Although $M$. merlangus individuals were not previously detected in ballast

476 tanks, marine organisms such as blennies and gobies (Wonham et al., 2000), and fish

477 eggs and larvae were detected (Carlton, 1985). Fish can survive up to 21 days in a range 478 of vessels (Wonham et al., 2000), making specimen survival and transport a possibility 479 for fish in general, and in this case for M. merlangus merlangus in particular.

\subsection{Conclusions}

482 In this study, the presence of diffent lineages between the Eastern Mediterranean 483 whiting ( $M$. m. euxinus) to those of the Atlantic (M. m. merlangus) were reported, however, our markers were not informative enough to support the taxonomic separation of the two presumed subspecies, especially given that the phylogenetic trees of individual markers failed to separate them in reciprocal monophyly. Additionally, our results showed that $M$. m. euxinus specimens across the main sampling areas of the North Aegean Sea, TSS, and Black Sea should be treated as different stocks, as restricted gene flow is reported across the Turkish locations. However, additional sampling in different parts of the Eastern Mediterranean and the Atlantic is required to define the distributional ranges of each presumed subspecies, whereas analyses are imperative to unravel gene flow among sampling locations, and hence to manage whiting stocks in these waters responsibly. Moreover, separate conservation measures and monitoring regimes are necessary for the protection of current stocks of whiting ( $M$. m. euxinus), as intense climate fluctuations and illegal and/or unregulated fishing could affect the species structure and dynamics. 
498 ACKNOWLEDGEMENTS

499 This study was supported by a grant (No: 1903) from the Research Fund of Boğaziçi

500 University in Istanbul to Raşit Bilgin. We would like to thank Dr. Gökhan Erik (Central

501 Fisheries Research Institute Fisheries Management in Trabzon), and anonymous

502 fishermen from the Sea of Marmara and the Black Sea for providing fish samples. The

503 authors declare that they have no conflict of interest. Finally, we are thankful to two

504 anonymous reviewers for their comments on a previous version of the manuscript. 


\section{REFERENCES}

Acara, A., 1957. Relation between the migration of Sarda sarda Bloch and prevailing temperature. Proceedings and Technical Papers, General Fisheries Council for the Mediterranean, FAO, Rome, 4,193-196.

Akşiray, F., 1987. Türkiye Deniz Baliklari ve Tayin Anahtari. Istanbul University Directorate Publication, 3490, 1-811. (in Turkish).

Avise, J.C., Arnold, J., Ball, R.M., Jr., Bermingham, E., Lamb, T., Neigel, J.E., Reeb, C.A., Saunders, N.C., 1987. Intraspecific phylogeography: The mitochondrial DNA bridge between population genetics and sytematics. Ann. Rev. Eco. Sys. 18, 489-522. https://doi.org/10.1146/annurev.es.18.110187.002421.

Avise, J.C., 2000. Phylogeography: The history and formation of species. Harvard University Press, Cambridge, MA.

Bailly, N., 2008. Merlangius merlangus. In: Froese, R. and D. Pauly. Editors. FishBase. Accessed through: World Register of Marine Species at http://www.marinespecies.org/aphia.php?p=taxdetails\&id=126438 on 2018-0106.

Bandelt, H.J., Forster, P., Röhl, A., 1999. Median-Joining Networks for inferring intraspecific phylogenies. Mol. Biol. Evol. 16, 37-48.

Bargelloni, L., Alarcon, J.A., Alvarez, M.C., Penzo, E., Margoulas, A., Reis, C., Patarnello, T., 2003. Discord in the family Sparidae (Teleostei): divergent phylogeographical patterns across the Atlantic-Mediterranean divide. J. Evol. Biol. 16, 1149-1158. https://doi.org/10.1046/j.1420-9101.2003.00620.x. 
Bektas, Y., Belduz, A.O., 2007. Molecular characterization of Whiting (Merlangius merlangus exinus Nordmann, 1840) in the Turkish Black Sea Coast by RAPD analysis. J. Ani. Vet. Adv. 6, 739-744.

Bektas, Y., Belduz, A.O., 2008. Molecular phylogeny of Turkish Trachurus species (Perciformes: Carangidae) inferred from mitochondrial DNA analyses. J. Fish Biol. 73, 1228-1248. https://doi.org/ 10.1111/j.1095-8649.2008.01996.x

Bektas, Y., Aksu, I., Kalayci, G., 2016. Türkiye'deki İsparoz (Diplodus annularis Linnaeus, 1758) Populasyonlarının mtDNA Cyt b Genine Dayalı Genetik Analizi. J. Anato. Environ. Ani. Sci. 2, 37-43. http://dergipark.gov.tr/jaes/issue/25813/273804. (in Turkish).

Borsa, P., Blanquer, A., Berrebi, P., 1997. Genetic structure of the flounders Platichthys fesus and P. stellatus at different geographic scales. Mar. Biol. 129, 233-246.

Bouckaert, R., Heled, J., Kühnert, D., Vaughan, T., Wu, C.H., Xie, D., Suchard, M.A., Rambaut, A., Drummond A.J., 2014. BEAST 2: a software platform for Bayesian evolutionary analysis. PLoS Comp. Biol. 10(4):e1003537. https://doi.org/ 10.1371/journal.pcbi.1003537.

Carlton, J., 1985. Transoceanic and interoceanic dispersal of coastal marine organisms: The biology of ballast water. Oceanogr. Mar. Biol. Ann. Rev. 23, 313-371.

Charrier, G., Coombs, S.H., McQuinn, I.H., Laroche, J., 2007. Genetic structure of whiting Merlangius merlangus in the northeast Atlantic and adjacent waters. Mar. Ecol. Progr. Series. 330, 201-211. https://doi.org/10.3354/meps330201.

Chevelot, M., Hoaraou, G., Rijnsdorp, A.D., Stam, W.T., Olsen, J.L., 2006. Phylogeography and population structure of thornback rays (Raja clavata L., Rajidae). Mol. Ecol. 15, 3693-3705. 
Chriki-Adeeb, R., Chriki, A., 2016. Estimating Divergence times and substitution rates in Rhizobia. Evol. Bioinform. 12, 87-97. https://doi: 10.4137/EBo.s39070.

Cimmaruta, R., Bondanelli, P., Nascetti, G., 2005. Genetic structure and environmental heterogeneity in the European hake (Merluccius merluccius). Mol. Ecol. 14, $2577-2591$.

Debes, P.V., Zachos, E., Hanel, R., 2008. Mitochondrial phylogeography of the European sprat (Sprattus sprattus L., Clupeidae) reveals isolated climatically vulnerable populations in the Mediterranean Sea and range expansion in the northeast Atlantic. Mol. Ecol. 17, 3873-3888.

Durand, J.D., Blel, H., Shen, K.N., Koutrakis, E.T., Guinand, B., 2013. Population genetic structure of Mugil cephalus in the Mediterranean and Black Seas: a single mitochondrial clade and many nuclear barriers. Mar. Ecol. Progr. Series 474, 243-261. https://doi.org/10.3354/meps10080.

Eiriksson, G.M., Arnason, E., 2014. Mitochondrial DNA sequence variation in whiting Merlangius merlangus in the North East Atlantic. Environ. Biol. Fishes 97, 103110. https://doi.org/10.1007/s10641-013-0143-5.

Ekman, S., 1967. Zoogeography of the sea. Sidgwick Johnson, Watergate editions, 9. xiv, $417 \mathrm{p}$.

Excoffier, L., Lischer, H.L., 2010. Arlequin suite ver 3.5: A new series of programs to perform population genetics analyses under Linux and Windows. Mol. Ecol. Res. 10, 564-567. https://doi.org/10.1111/j.1755-0998.2010.02847.x.

FAO, 2017. Sixth meeting of the Working Group on the Black Sea (WGBS) https://gfcm.sharepoint.com/EG/Report\%20v2/2017/WGBS/FI/GFCM_WGBS 2017. Report.pdfslrid=3467619e-900e-5000-e898b0fe5b07d125, accessed, (20.04.2018). 
Fischer, W., Bauchot, M.L., Schneider, M., 1987. Fiches FAO d'identification des espèces pour les besoins de la pêche. (Rvision 1). Mditerrane et mer Noire. Zone de pêche 37. Volume II. Vertébrés. Publication préparée par la FAO, résultat d'un accord entre la FAO et la Commission des Communauts Europennes (Project GCP/INT/422/EEC) financée conjointement par ces deux organisations. Rome, FAO, 2, 761-1530. (in French).

Fu, Y.X., 1997. Statistical tests of neutrality of mutations against population growth, hitchhiking and background selection. Genetics 147 (2), 915-925.

Fontaine, M.C., Snirca, A., Frantzisc, A., Koutrakisd, E., Öztürk, B., Öztürk, A.A., Austerlitz, F., 2012. History of expansion and anthropogenic collapse in a top marine predator of the Black Sea estimated from genetic data. PNAS 109, E2569-E2576. https://doi.org/10.1073/pnas.1201258109.

Harpending, H.C., 1994. Signature of ancient population growth in a low-resolution mitochondrial DNA mismatch distribution. Human Biol. 66 (4), 591-600.

Harpending, H.C., Sherry, S.T., Rogers, A.R., Stoneking, M., 1993. The genetic structure of ancient human populations. Curr. Anthr. 34, 483-496.

Heled J., Drummond A.J., 2008. Bayesian inference of population size history from multiple loci. BMC Evol.Biol. 8, 289. https:// doi:10.1186/1471-2148-8-289.

HELCOM, 2013. Climate change in the Baltic Sea Area HELCOM thematic assessment in 2013. Baltic Sea Environment Proceedings No. 137, Helsinki Commission Baltic Marine Environment Protection Commission Report 66 p.

Hislop, J.R.G., 1984. A comparison of reproductive tactics and strategies of cod, haddock, whiting and Norway pout in the North Sea. In fish reproduction: strategies and tactics (eds. G., W. Potts \& R.J. Wotton), pp. 319-329. London Academic Press. 
Ho, S.Y.W., Shapiro, B., 2011. Skyline-plot methods for estimating demographic history from nucleotide sequences. Mol. Ecol. Res. 11, 423-434. https://doi.org/10.1111/j.1755-0998.2011.02988.x

Ho, S.Y.W., Phillips, M.J., Cooper, A., Drummond, A.J., 2005. Time dependency of molecular rate estimates and systematic overestimation of recent divergence times. Mol. Biol. Evol. 22, 1561-1568.

IUCN, 2011. IUCN Red List of Threatened Species (ver. 2011.2). Available at: http://www.iucnredlist.org. (Accessed: 10 November 2016).

İşmen, A., 1995. Fecundity of whiting, Merlangius merlangus euxinus (L.) on the Turkish Black Sea coast. Fish. Res. 22 (3,4), 309-318. https://doi.org/10.1016/0165-7836(94)00327-S.

İssmen, A., 2001. Use of discriminant function for morphometric and meristic variation of whiting stocks, Merlangius merlangus euxinus, along the Turkish Black Sea Coast. Turkish J. Zool. 25, 297-304.

Kanarska, Y., Maderich, V., 2008. Modelling of seasonal ex-change flows through the Dardanelles Strait. Estuar. Coast. Shelf Sci. 79 (3), 449-458.

Karahan, A., Douek, J., Paz, G., Stern, N., Kideys, A.E., Shaishb, L., Gorenc, M., Baruch, R., 2017. Employing DNA barcoding as taxonomy and conservation tools for fish species censuses at the southeastern Mediterranean, a hot-spot area for biological invasion. J. Nat. Conserv. 36, 1-9. https://doi.org/10.1016/j.jnc.2017.01.004.

Keskin, E., Can, A., 2009. Phylogenetic relationships among four species and a subspecies of Mullidae (Actinopterygii; Perciformes) based on mitochondrial cytochrome b, 12S rRNA and cytochrome oxidase II genes. Bioch. Syst. Ecol. 37, 653-661. https://doi.org/10.1016/j.bse.2009.10.001. 
Kimura, M., 1980. A simple method for estimating evolutionary rates of base substitutions through comparative studies of nucleotide sequences. J. Mol. Evol. 16, 111-120. https://doi.org/10.1007/BF01731581.

Kocataş, A., Koray, T., Kaya, M., Kara, O.F., 1993. A review of the fishery resources and their environment in the Sea of Marmara. General Fisheries Commision for the Mediterranean (GFCM). Studies and Reviews, 64, FAO. 87-143.

Kochzius, M., Seidela, C., Antoniou, A., Botlal, S.K., Campo, D., Cariani, A., Vazquez, E.G., Hauschild, J., Hervet, H.S., Hreggvidsson, G., Kappel, K., Landi, M., Magoulos, A., Marteinsson, V., Nolte, M., Planes, S., Tinti, T., Turan, C., Venugopal, M.N., Weber, H., Blohm, D., 2010. Identifying Fishes through DNA Barcodes and Microarrays. Plos One 5 (9), 1-15. https://doi.org/10.1371/journal.pone.0012620.

Kumar, S., Stecher, G., Tamura, K., 2016. MEGA7: Molecular Evolutionary Genetics Analysis Version 7.0 for Bigger Datasets. Mol. Biol. Evol. 33 (7), 1870-1874. https://doi.org/10.1093/molbev/msw054.

Ladoukakis, E.D., Saavedra, C., Magoulas, A., Zouros, E., 2002. Mitochondrial DNA variation in a species with two mitochondrial genomes: the case of Mytilus galloprovincialis from the Atlantic, the Mediterranean and the Black Sea. Mol. Ecol. 11, 755-769.

Lambeck, K., Yokoyama, Y., Purcella, T., 2002. Into and out of the Last Glacial Maximum: sea-level change during Oxygen Isotope Stages 3 and 2. Quaternary Sci. Rev. 21, 343-360.

Lanfear, R., Calcott, B., Ho, S.Y.W., Guindon, S., 2012. PartitionFinder: combined selection of partitioning schemes and substitution models for phylogenetic analyses. Mol. Biol. Evol. 29, 1695-1701. 
Leigh, J.W., Bryant, D., 2015. POPART: full-feature software for haplotype network construction. Methods Ecol. Evol. 6, 1110-1116.

Librado, P., Rozas, J., 2009. DnaSP v5: A software for comprehensive analysis of DNA polymorphism data. Bioinformatics 25, 1451-1452.

Limborg, M.T., Hanel, R., Debes, P.V., Ring, R., Andre, C., Tsigenopoulos, C.S., Bekkevold, D., 2012. Imprints from genetic drift and mutation imply relative divergence times across marine transition zones in a pan-European small pelagic fish (Sprattus sprattus). Heredity 109, 96-107. https://doi:10.1038/hdy.2012.18.

Magoulas, A.N., Tsimenides, N., Zouros, E., 1996. Mitochondrial DNA phylogeny and the reconstruction of the population history of a species: The case of the European anchovy (Engraulis encrasicolus). Mol. Biol. Evol. 13, 178-190. https://doi.org/10.1093/oxfordjournals.molbev.a025554.

Magoulas, A., Castilho, R., Caetano, S., Marcato, S., Patarnello, T., 2006. Mitochondrial DNA reveals a mosaic pattern of phylogeographical structure in Atlantic and Mediterranean populations of anchovy (Engraulis encrasicolus). Mol. Phyl. Evol. 39, 734-746. https://doi.org/10.1016/j.ympev.2006.01.016.

Moraitou-Apostolopoulou, M., 1985. The zooplankton communities of the Eastern Mediterranean (Levantine basin, Aegean Sea); influence of man-made factors, 303- 331 in M. Mora1tou-Apostolopoulou an d V. Kiorts1s, eds. Mediterranean marine ecosystems. Plenum Press, New York, London.

Nedreaas, K., Florin, A., Cook, R., Fernandes, P., Lorance, P., 2014. Merlangius merlangus. The IUCN Red List of Threatened Species 2014: e.T198585A45097610. https://dx.doi.org/10.2305/IUCN.UK.2014,3.RLTS.T198585A45097610.en. 
Nei, M., 1987. Molecular Evolutionary Genetics. Columbia University Press, New York, 512.

Nei, M., Tajima, F., 1981. DNA polymorphism detectable by restriction endonucleases. Genetics 97 (1), 145-163.

O’Regan, M., Williams, C.J., Frey, K.E., Jakobsson, M., 2011. A synthesis of the longterm paleoclimatic evolution of the Arctic. Oceanography 3, 66-80.

Özdamar, E., Samsun, O., Kihara, K., Sakuramoto, K., 1996. Stock assesment of whiting, Merlangius merlangus euxinus along the Turkish coast of Black Sea. J. Tokyo Univ. Fish. 82 (2), 135-149.

Özdemir, S., Söyleyici, H., Özdemir, Z.B., Özsandıkçı, U., Büyükdeveci, F., 2018. Karadeniz (Sinop-Samsun) Kıyılarında Avlanan Mezgit (Merlangius merlangus euxinus) Balığının Aylık Olarak Boy-Ağırlık İlişkileri ve Boy Kompozisyonunun Tespiti. Aquat. Res. 1 (1), 26-37. DOI: 10.3153/AR18004. (in Turkish).

Öztürk, B., Öztürk, A.A., 1996. On the biology of the Turkish straits system. Bulletin de l'Institut Ocanographique, Monaco, no special 17. CIESM Science Series n2. 205-221.

Öztürk, B., 1998. Black Sea biological diversity: Turkey, compiled by Bayram Öztürk and Turkish Marine Research Foundation, New York: United Nations Publications, 1-314.

Patarnello, T., Volckaert, F.A., Castilho, R., 2007. Pillars of Hercules: is the AtlanticMediterranean transition a phylogeographical break? Mol. Ecol. 16, 4426-4444. 
Parin, N.W., Evseenko, S.A.,Vasileva, E.D., 2014. Fishes of Russian Seas Annotated Catalogoue, Moscow, KMK, Scientific Press, 733.p.

Peijnenburg, K.T.C.A., Breeuwer, J.A.J., Pierrot-Bults, A.C., Menken, S.B.J., 2004. Phylogeography of the planktonic chaetognath Sagitta setosa reveals isolation in European Seas. Evolution 58, 1472-1487. https://doi.org/10.1554/03-638.

Pilcher, M.W., Whitfield, P.J., Riley, J.D., 1989. Seasonal and regional infestation characteristics of three ectoparasites of whiting, Merlangius merlangus L., in the North Sea. J. Fish Biol. 35 (1), 97-110. https://doi.org/10.1111/j.10958649.1989.tb03396.x.

R Core Team, 2018. R: A language and environment for statistical computing. R Foundation for Statistical Computing, Vienna, Austria. URL, https://www.Rproject.org/.

Rambaut, A., Suchard, M.A., Xie, D., Drummond, A.J., 2014. Tracer v1.6, Available from http://beast.community/tracer.

Rice, W.R., 1989. Analyzing tables of statistical tests. Evolution 43 (1), 223-225. https://doi.org/10.1111/j.1558-5646.1989.tb04220.x.

Rico, C., Ibrahim, K.M., Rico, I., Hewitt, G.M., 1997. Stock composition in North Atlantic populations of whiting using microsatellite markers. J. Fish Biol. 51, 462-475. https://doi.org/10.1111/j.1095-8649.1997.tb01504.x.

Roberti, M., Yannopoulos, G., De Metrio, G., Ludovico, A., Milella, F., Carone, P., Megalofonou, P., Bingel, F., Ünlüata, U., Cantatore, P., Gadaleta, M.N., 1993. Polimorfismo del DNA mitochondriale in stock di palamita, Sarda sarda, del Mar Mediterraneo. Biologia Marina Suppl. Notiz. SIBM. 1, 349-353. (in Italian). 
Rogers, A.R., Harpending, H., 1992. Population growth makes waves in the distribution of pairwise genetic differences. Mol. Biol. Evol. 9 (3), 552-569. https://doi.org/10.1093/oxfordjournals.molbev.a040727.

Rohling, E.J., Abu-Zieb, R., Casford, J.L.S., Hayes, A., Hoogakker, B.A.A., 2009. The marine environment: Present and Past. The Physical Geography of the Mediterranean, ed. Woodward JC (Oxford Univ Press, Oxford), pp 33-67.

Ronquist, F., Teslenko, M., Mark, P.V.D., Ayres, D.L., Darling, A.S., Höhna, S., Larget, B., Liu, L., Suchard, M.A., Huelsenbeck, J.P., 2012. MrBayes 3.2: efficient Bayesian phylogenetic inference and model choice across a large model space. Syst. Biol. 61, 1-4.

Roques, S., Fox, C.J., Villasana, M.I., Rico, C., 2006. The complete mitochondrial genome of the whiting, Merlangius merlangus and the haddock, Melanogrammus aeglefinus: A detailed genomic comparison among closely related species of the Gadidae family. Gene 383, 12-23. https://doi.org/10.1016/j.gene.2006.06.018.

Rosel, P.E., Block, B.A., 1996. Mitochondrial control region variability and global population structure in the swordfish, Xiphias gladius. Mar. Biol. 125 (1), 1122. https://doi.org/10.1007/BF00350756.

Ryan, W.B.F., Pitmann, W.C., Major, C., Shimkus, K., Moskalenko, V, Jones, G.A., Dimitrov, P., Görür, N., Sakinc, M., Yüce, H., 1997. An abrupt drowning of the Black Sea shelf. Mar. Geol. 138, 119-126.

Sayın, E., Eronat, C., Uçkaç, Ş., Beşiktepe, Ş.T., 2011. Hydrography of the eastern part of the Aegean Sea during the Eastern Mediterranean Transient (EMT). J. Marine Syst. 88, 502-515. 
Shlyakhov, V., Charova, I., 2003. The Status of the Demersal Fish Population along the Black Sea Cost of Ukraine. In: Workshop on Demersal Resources in the Black \& Azov Sea. Published by Turkish Marine Research Foundation, Istanbul, TURKEY, B. Öztürk and S. Karakulak (Eds.), 65-74.

Slatkin, M., Hudson, R.R., 1991. Pairwise comparisons of mitochondrial DNA sequences in stable and exponentially growing populations. Genetics 129 (2), $555-562$.

Stamatakis, A., 2014. RAxML version 8: a tool for phylogenetic analysis and postanalysis of large phylogenies. Bioinformatics 30, 1312-1313.

Suziki, N., Nishida, M., Yoseda, K., Üstündağ, C., Şahin, T., Amaoka, K., 2004. Phylogeographic relationships within the Mediterranean turbot inferred by mitochondrial DNA haplotype variation. J. Fish. Biol. 65, 580-585. https://doi:10.1111/j.1095-8649.2004.00433.x.

Tajima, F., 1989. Statistical method for testing the neutral mutation hypothesis by DNA polymorphism. Genetics 123 (3), 585-595.

Turan, C., Oral, M., Öztürk, B., Düzgüneş, E., 2006. Morphometric and meristic variation between stocks of Bluefish (Pomatomus saltatrix) in the Black, Marmara, Aegean and northeastern Mediterranean Seas. Fish. Res. 79, 139-147. https://doi.org/10.1016/j.fishres.2006.01.015.

Turan, C., Öztürk, B., Çalışkan, M., Düzgüneş, E., Gürlek, M., Yağlığlu, D., Hazar, D., Sevenler, S., 2009a. Genetic variation of Atlantic horse mackerel (Trachurus trachurus) in the Turkish waters. Cah. Biol. Mar. 50, 207-213.

Turan, C., Gürlek, M., Yağlıoğlu, D., Öztürk, B., 2009b. Genetic differentiation Mediterranean horse mackerel (Trachurus mediterraneus) populations as 
revealed by mtDNA PCR-RFLP analysis. J. App. Ichth. 25, 142-147. https://doi.org/10.1111/j.1439-0426.2009.01223.x.

Turan, C., Ergüden, D., Çevik, C., Turan, F., 2015a. Molecular Systematic Analysis of Shad Species (Alosa spp.) from Turkish Marine Waters using mtDNA Genes. Turkish J. Vet. Anim. Sci. 15, 149-155. doi: 10.4194/1303-2712-v15_1_16.

Turan, C., Gürlek, M., Ergüden, D., Yağlioglu, D., Uyan, A., Reyhaniye, A.N., Özbalcilar, B., Öztürk, B., Erdoğan, Z.A., Ivanova, P., Soldo, A., 2015 b. Population genetic analysis of Atlantic bonito Sarda sarda (Bloch, 1793) using sequence analysis of mtDNA D-loop region. Fres. Environ. Bull. 24, 3148-3154.

Viaud-Martínez, K.A., Brownell, R.L., Komnenou, A., Bohonak, A.J., 2008. Genetic isolation and morphological divergence of Black Sea bottlenose dolphins. Biol. Cons. 141, 1600-1611. https://doi.org/10.1016/j.biocon.2008.04.004.

Waelbroeck, C., Labeyrie, L., Michel, E., Duplessy, J.C., McManus, J.F., Lambeck, K., Balbon, E., Labracherie, M., 2002. Sea-level and deepwater temperature changes derived from benthic foraminiferaisotopic records. Quaternary Sci. Rev. 21, 295305.

Whitehead, P.J.P., Bauchot, M.L., Hureau, J.C., Nilsen, J., Tortonese, E., 1986. Fishes of the North-Eastern Atlantic and the Mediterranean. UNESCO: London. 510 pp.

Xia, X., 2017. DAMBE 6. New tools for microbial genomic, phylogenetics and molecular evolution. J. Hered. 108, 431-437. https://doi.org/10.1093/jhered/esx033.

Wonham, M.J., Carlton, J.T., Ruiz, G.M., Smith, L.D., 2000. Fish and ships: Relating dispersal frequency to success in biological invasions. Mar. Biol. 136, 11111121. https://doi.org/10.1007/s002270000303. 
Zaitsev, Y., Mamaev, V., 1997. Marine Biological Diversity in the Black Sea. A Study of the Change and Decline. Vol. XV. United Nations Publications, New York, pp. 1-208.

Zardoya, R., Castilho, R., Grande C., Favre-Krey, L. Caetano, S., Marcato, S., Krey, G., Patarnello, T., 2004. Differential population structuring of two closely related fish species, the mackerel (Scomber scombrus) and the chub mackerel (Scomber japonicus), in the Mediterranean Sea. Mol. Ecol. 13, 1785-1798. https://doi.org/10.1111/j.1365-294X.2004.02198.x.

Zhang, J.B., Hanner, R., 2011. DNA barcoding is a useful tool for the identification of marine fishes from Japan. Bioch. Syst. Ecol. 39, 31-42. https://doi.org/10.1016/j.bse.2010.12.017.

Zheng, X.D., Wang, R.C., Wang, X.F., Xiao, S, Chen, B., 2001. Genetic variation in populations of the common Chinese cuttlefish Sepiella maindroni (Mollusca: Cephalopoda) using allozymes and mitochondrial DNA sequence analysis. J. Shellfish Res. 20 (3), 1159-1165. 


\section{TABLES}

TABLE 1. Pairwise $\Phi_{\mathrm{ST}}$ values for the COI+cyt-b data, below diagonal and $F_{S T}$ values for the RAG1 above diagonal of Merlangius merlangus euxinus. Values in italics and bold were significant before and after Bonferroni corrections, respectively.

\begin{tabular}{|c|c|c|c|c|c|c|c|c|c|c|c|}
\hline & & & & $\begin{array}{l}\bar{\Xi} \\
\bar{\Xi} \\
. \triangleq \Xi\end{array}$ & 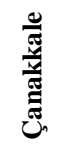 & 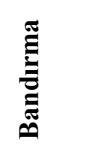 & $\stackrel{\mathscr{\Xi}}{\approx}$ & 音 & 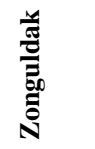 & 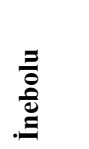 & 窇 \\
\hline \multirow{8}{*}{ 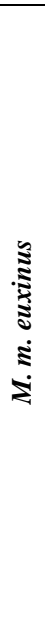 } & \multirow{3}{*}{\multicolumn{2}{|c|}{2}} & Istanbul & - & 0.041 & 0.031 & 0.132 & -0.004 & 0.013 & -0.015 & 0.187 \\
\hline & & & Çanakkale & 0.022 & - & 0.011 & 0.013 & -0.014 & 0.011 & 0.078 & 0.129 \\
\hline & & & Bandirma & -0.045 & 0.021 & - & 0.125 & 0.009 & -0.017 & 0.033 & 0.057 \\
\hline & \multirow{4}{*}{ 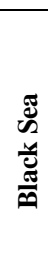 } & \multirow{4}{*}{ 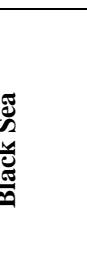 } & Rize & 0.029 & 0.097 & -0.028 & - & 0.074 & 0.102 & 0.258 & 0.230 \\
\hline & & & Sinop & 0.178 & 0.364 & 0.163 & 0.082 & - & -0.004 & 0.024 & 0.183 \\
\hline & & & Zonguldak & 0.127 & 0.295 & 0.019 & -0.013 & 0.109 & - & -0.021 & 0.119 \\
\hline & & & Inebolu & 0.102 & 0.294 & 0.097 & 0.026 & 0.001 & 0.086 & - & 0.253 \\
\hline & $\tilde{z}$ & لٌّ & Greece & 0.219 & 0.316 & 0.175 & 0.178 & 0.354 & 0.210 & 0.156 & - \\
\hline
\end{tabular}


TABLE 2. Hierarchical AMOVA results COI+cyt-b (top) and RAG 1 genes (bottom).

\begin{tabular}{|c|c|c|c|c|c|c|}
\hline & $\begin{array}{l}\text { Source of } \\
\text { variation }\end{array}$ & $\begin{array}{l}\text { Total } \\
\text { variation }\end{array}$ & $\begin{array}{l}\text { Percent of } \\
\text { total }\end{array}$ & $\Phi_{C T} / \mathbf{F}_{C T}$ & $\Phi_{S C} /$ Fsc & $\Phi_{S T} / \mathbf{F}_{\mathrm{ST}}$ \\
\hline \multirow{4}{*}{ 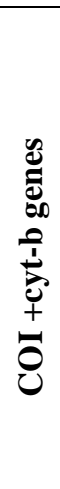 } & Among groups & 0.1697 & 15.80 & 0.1580 & & \\
\hline & $\begin{array}{l}\text { (TSS, Black Sea, } \\
\text { N. Aegean Sea) } \\
\text { Among } \\
\text { populations } \\
\text { within groups }\end{array}$ & 0.0272 & 2.53 & $(\mathrm{p}=0.0049)$ & $\begin{array}{l}0.0300 \\
(p=0.2160)\end{array}$ & \\
\hline & $\begin{array}{l}\text { Within } \\
\text { populations }\end{array}$ & 0.8773 & 81.67 & & & $\begin{array}{l}0.1833 \\
(p=0.0000)\end{array}$ \\
\hline & Total & 1.0741 & & & & \\
\hline \multirow{4}{*}{ שَ } & $\begin{array}{l}\text { Among groups } \\
\text { (TSS, Black Sea, } \\
\text { N. Aegean Sea) }\end{array}$ & 0.0190 & 4.18 & $\begin{array}{l}0.04186 \\
(\mathrm{p}=0.1386)\end{array}$ & & \\
\hline & $\begin{array}{l}\text { Among } \\
\text { populations } \\
\text { within groups }\end{array}$ & 0.0202 & 4.46 & & $\begin{array}{l}0.0466 \\
(p=0.0106)\end{array}$ & \\
\hline & $\begin{array}{l}\text { Within } \\
\text { populations }\end{array}$ & 0.4138 & 91.34 & & & $\begin{array}{l}0.0866 \\
(p=0.0000)\end{array}$ \\
\hline & Total & 0.4530 & & & & \\
\hline
\end{tabular}




\section{FIGURE CAPTIONS}

FIGURE 1. Sampling locations of Merlangius merlangus euxinus [(this study (red diamond symbol), GenBank (red dotted circle symbol)], M. m. merlangus [(this study (yellow triangle), and GenBank (the yellow dotted circle symbol)]. The red dashed line represents the distribution of $M$. m. euxinus according to Bailly (2008) and Parin et al. (2014). Numbers on the figures indicate sampling locations. Localities information are found in Supplementary Table 1.

FIGURE 2. Haplotype networks of a) COI, b) cyt-b and c) RAG1 genes of Merlangius merlangus. Note: Yellow color indicates Merlangius merlangus euxinus and pink indicates Merlangius merlangus merlangus.

FIGURE 3. Extended Bayesian Skyline Plots for the concatenated COI, cyt-b, RAG1 genes of Merlangius merlangus euxinus, a) North Aegean Sea, b) TSS, and c) Black Sea populations reflecting changes in effective population size against time in thousands of years (Ya) before present. Central posterior density intervals are indicated as 95\% CPD.

FIGURE 4. BEAST chronogram based on the concatenated COI, cyt-b, RAG1 genes of Merlangius merlangus without outgroup dating. Values above branches are the mean node height (age). Bars show 95\% HPD. Values below branches are posterior probabilities. Legends indicate localities. 


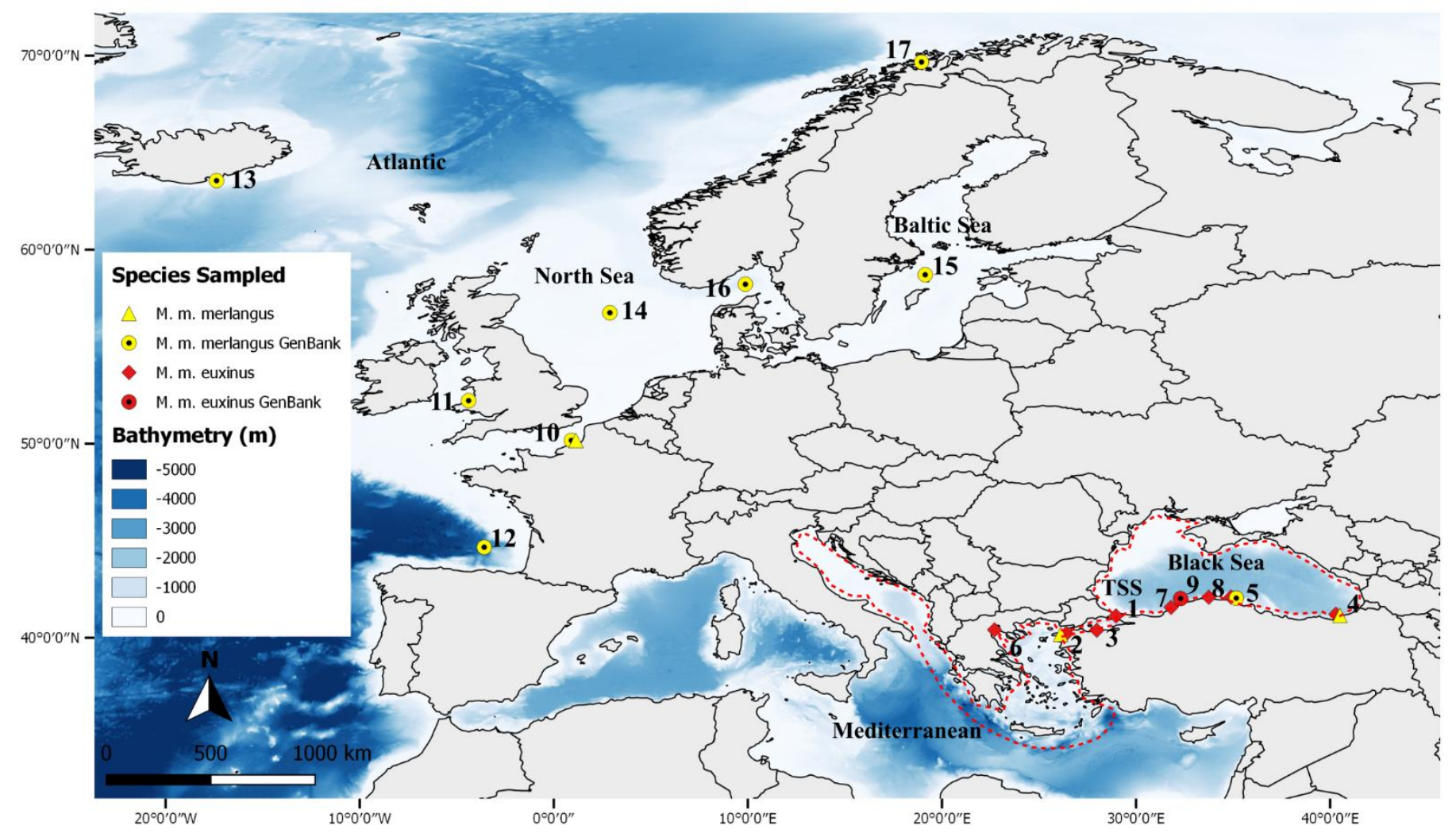


a

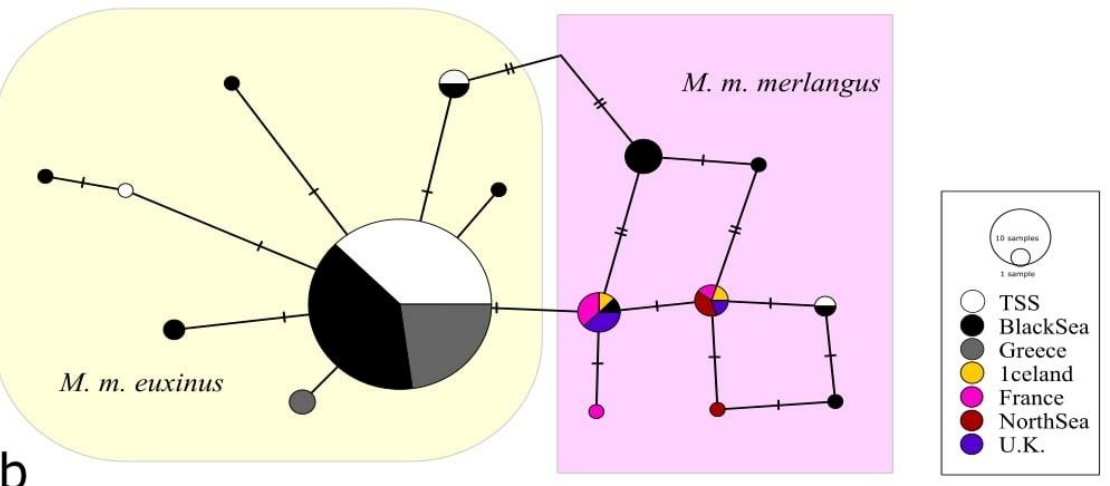

b

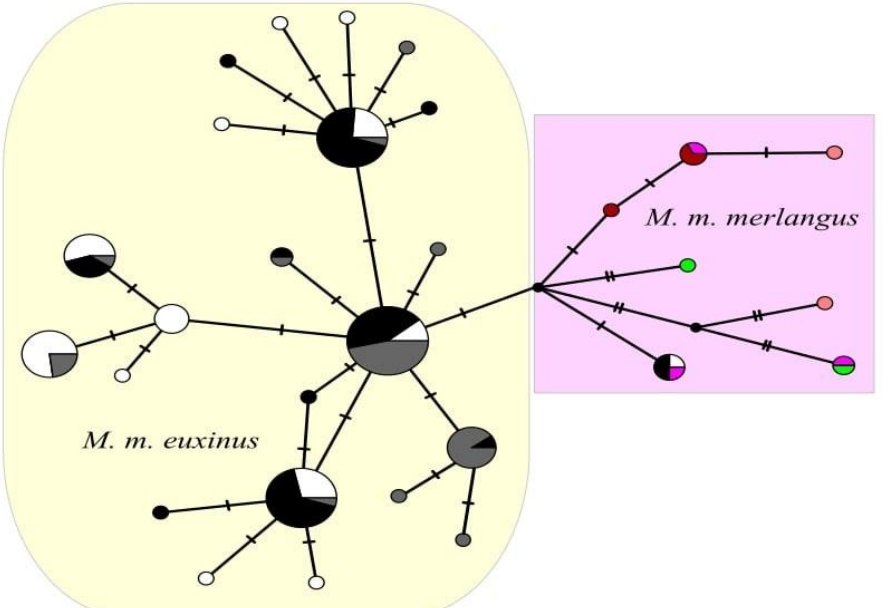

$\begin{array}{|ll|} & \text { TSS } \\ 8 & \text { BlkSea } \\ 8 & \text { Greece } \\ 8 & \text { France } \\ 8 & \text { BayBiscay } \\ 8 & \text { NorthSea } \\ \bigcirc & \text { BalticSea }\end{array}$

C

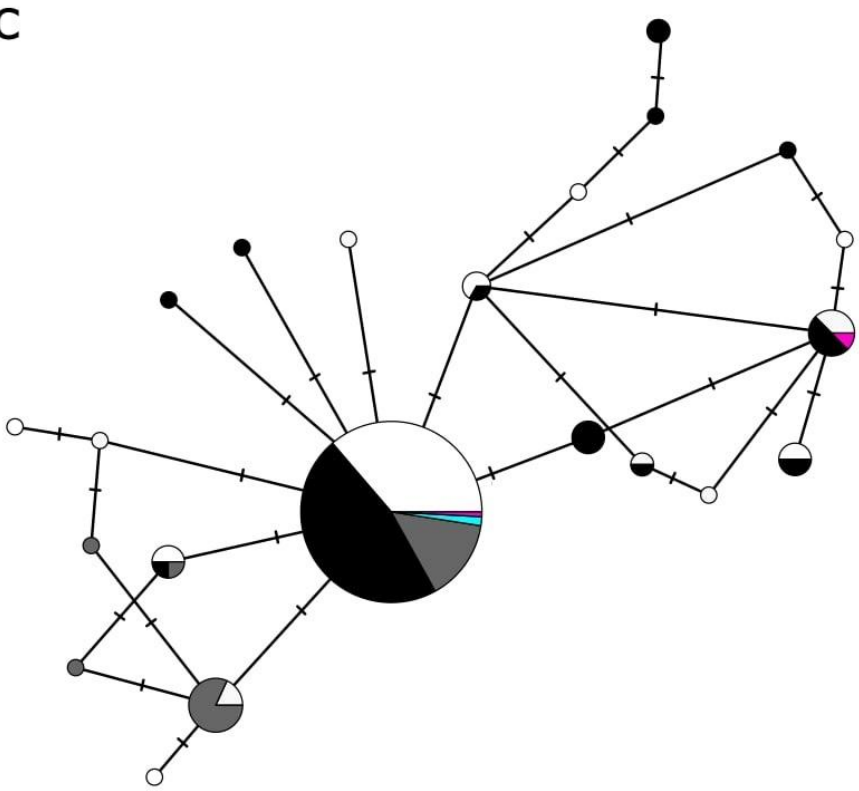

$\begin{array}{ll}\text { TSS } \\ \bigcirc \text { BlackSea } \\ \bigcirc & \text { Greece } \\ \bigcirc & \text { Tromso } \\ \bigcirc & \text { France }\end{array}$ 
a)

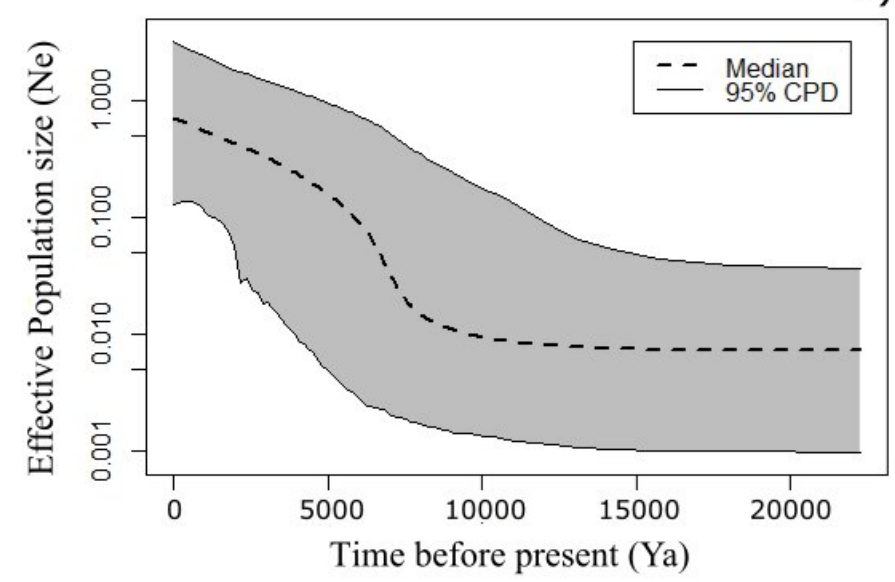

b)

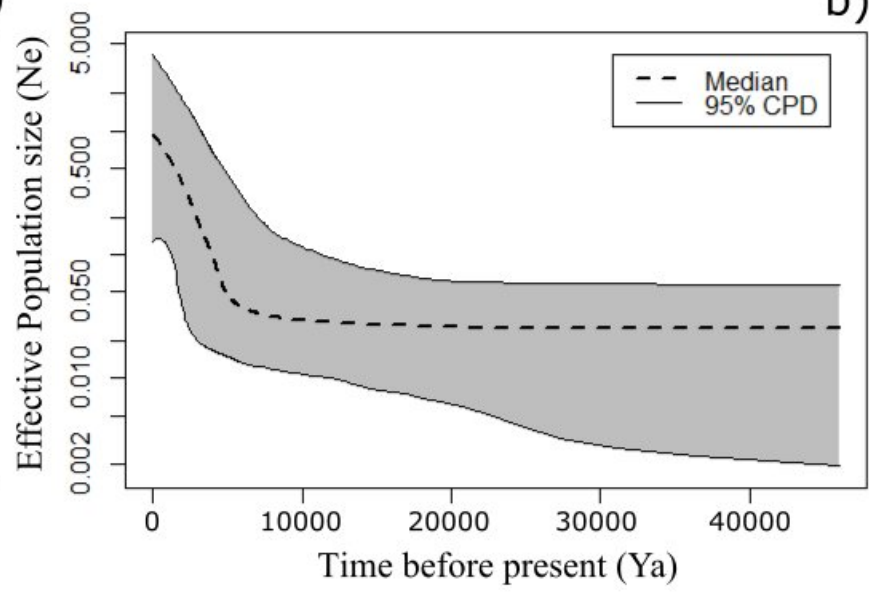

c)

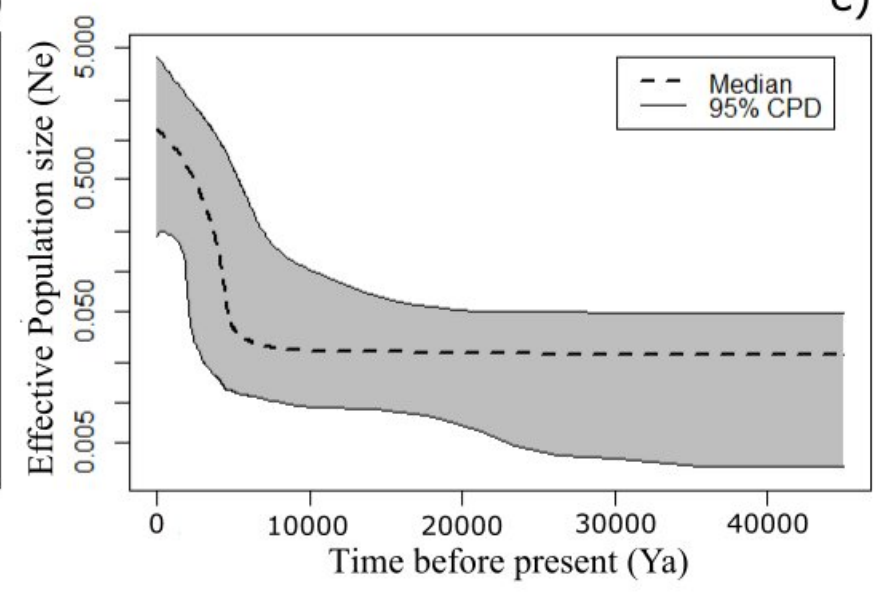




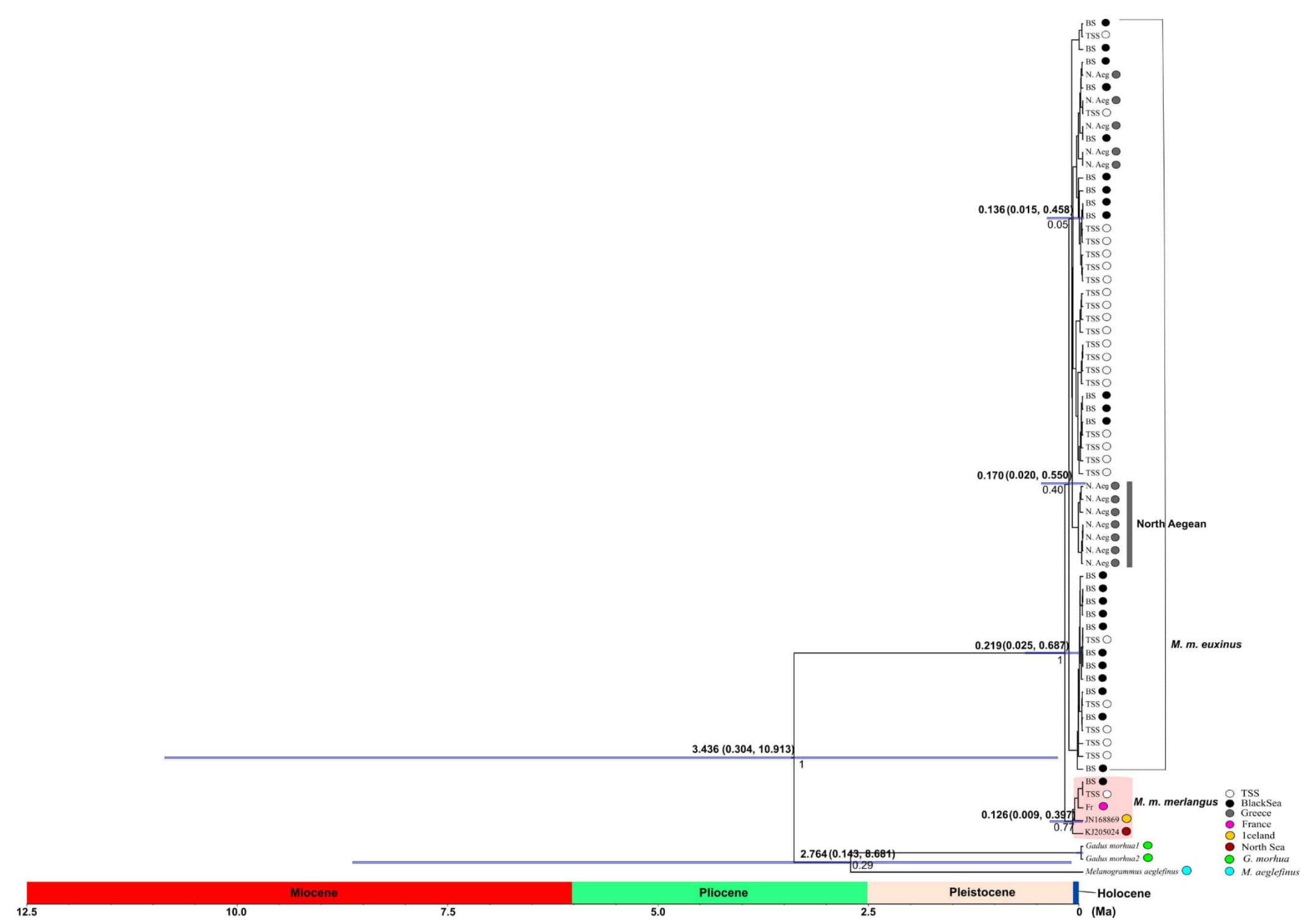

